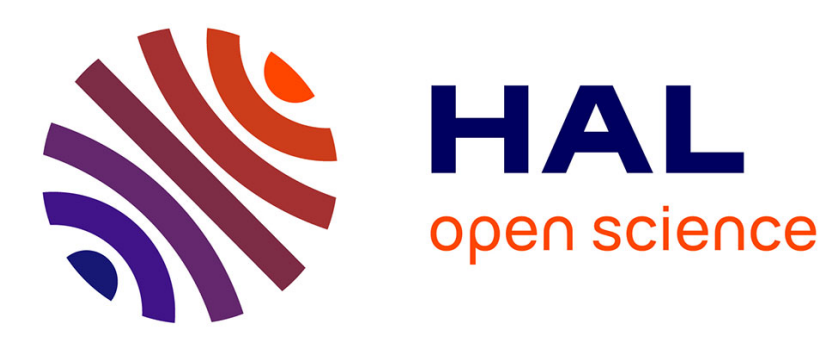

\title{
Échaillon stone from France: a Global Heritage Stone Resource proposal \\ Thierry Dumont
}

\section{To cite this version:}

Thierry Dumont. Échaillon stone from France: a Global Heritage Stone Resource proposal. The Geological Society, London, Special Publications, 2020, 486 (1), pp.115-128. 10.1144/SP486-201992 . hal-03086304

\section{HAL Id: hal-03086304 https://hal.science/hal-03086304}

Submitted on 22 Dec 2020

HAL is a multi-disciplinary open access archive for the deposit and dissemination of scientific research documents, whether they are published or not. The documents may come from teaching and research institutions in France or abroad, or from public or private research centers.
L'archive ouverte pluridisciplinaire HAL, est destinée au dépôt et à la diffusion de documents scientifiques de niveau recherche, publiés ou non, émanant des établissements d'enseignement et de recherche français ou étrangers, des laboratoires publics ou privés. 


\title{
Échaillon stone from France: a Global Heritage Stone Resource proposal
}

\author{
By THIERRY DUMONT ${ }^{1 *}$, and SPIA $^{2}$
}

1. Univ. Grenoble Alpes, Univ. Savoie Mont Blanc, CNRS, IRD, IFSTTAR, ISTerre, 38000 Grenoble, France.

2. SPIA (Sauvegarde du Patrimoine Industriel d'Autrefois - Yesteryear Industrial Heritage Preservation), a local society dedicated to preservation of Échaillon quarries and to promotion of Échaillon stone, as well as the industrial heritage of the village, 38210 Saint-Quentin-sur-Isère, France.

*Correspondence (thierry.dumont@univ-grenoble-alpes.fr)

TD ORCiD: 0000-0002-1204-7901

\begin{abstract}
Échaillon stone, a Mesozoic platform limestone from SE France, is proposed as a Global Heritage Stone Resource. The Échaillon stone quarries are located at the western termination of the Alps, near the city of Grenoble. Stone from the main Échaillon quarries is an Upper Jurassic to Berriasian bioclastic near-reef limestone, renowned for its two characteristic white and pink colours. Two ancillary quarries nearby, the Lignet and Rovon quarries, provided the Lower Cretaceous (Barremian to Aptian) Yellow Échaillon stone, of lagoonal origin. The Échaillon stone's unique characteristics, resistance to weathering and high aesthetic values made it a prized building and ornamental material used in many significant historic buildings in Europe, North Africa, and the United States. Although the first use of the Échaillon stone in buildings dates from the Gallo-Roman period, the industrial use ranges from the middle 19th century, during the heyday of the Beaux-Arts architecture building period in France, to the middle 20th century. The reputation of the Échaillon stone was bolstered by worldrenowned architects, sculptors, and artists that used it for historical building ornament and sculptures. By the turn of the 20th century, production started to decline and production ceased by the middle 20 th century.
\end{abstract}

\section{Keywords:}

platform limestone, Jurassic, Cretaceous, quarry, heritage, building, sculpture.

\section{Introduction}

Échaillon stone is a Mesozoic reefal limestone quarried in south-eastern France. The first record of the use of the stone in buildings dates from the Gallo-Roman period. Its industrial exploitation developed in the latter half of the 19th century during the heyday of the BeauxArts architecture building period in France. By the turn of the 20th century, the quarries' operations started to decline but continued until the middle of the century when all quarry operations eventually ceased. The Échaillon quarries are located in the western Alps of SE 
France, at the north-western edge of the Vercors Massif, approximately $15 \mathrm{~km}$ from the city of Grenoble, at Saint-Quentin-sur-Isère (Fig. 1).

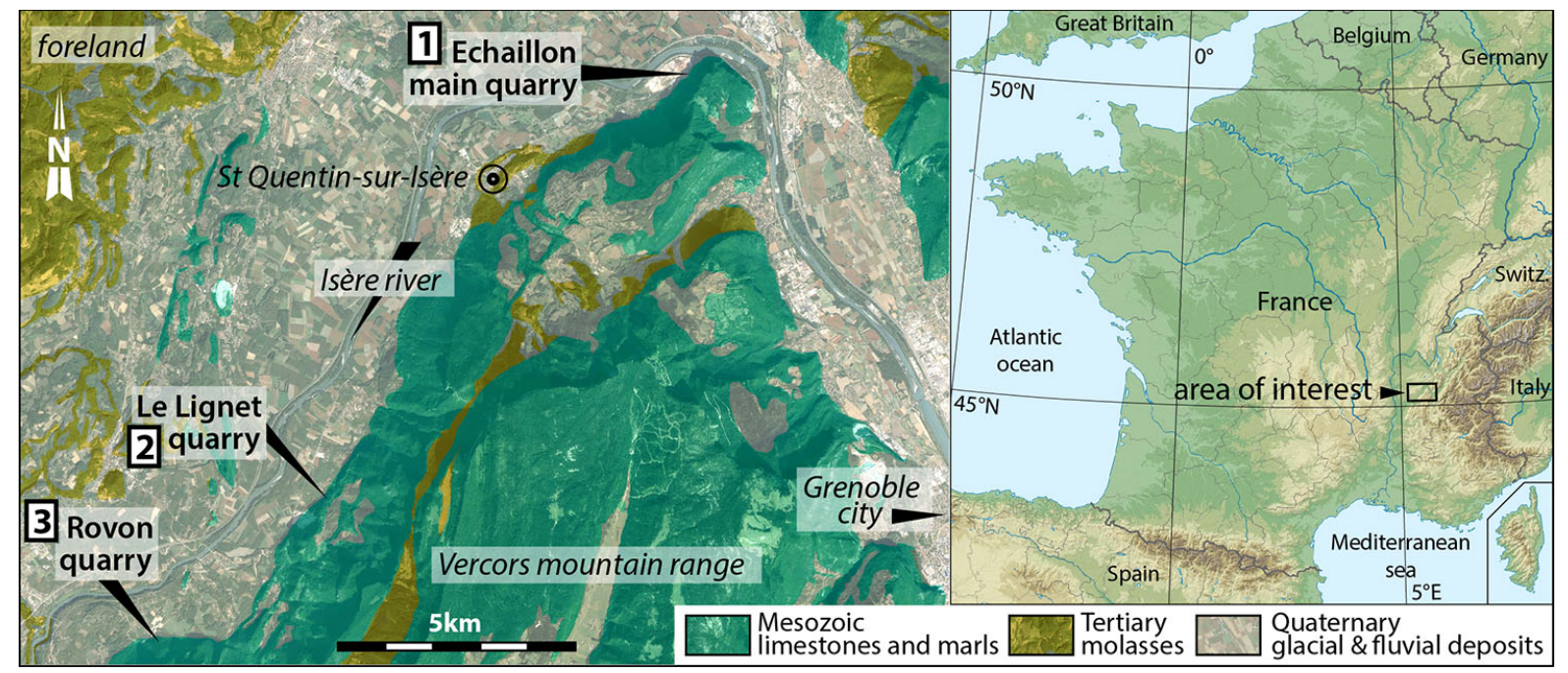

Fig. 1. Location of Échaillon Stone quarries at the western edge of the western Alpine chain: Échaillon (1) Lignet (2) and Rovon (3).

Quarrying of the Échaillon stone was carried out at three locations: the oldest Échaillon quarry is represented by a late Jurassic age shallow water reefal limestone that prograded from the Jura platform. The lithology of the Lignet quarry and the Rovon quarry limestone are part of the widespread early Cretaceous shallow water Urgonian formation that is the main fabric of the Vercors Massif. These quarries developed during the late 19th and early 20th century are no longer active. However, the quarries are still largely accessible for geologic research.

The Échaillon stone was used in many significant historic buildings including the Grand Opera House and Alexander III Bridge in Paris, and for many sculptures and buildings all over France and Europe, as well as America and Africa. It was the preferred ornamental stone of famous sculptors such as Bartholdi, Carpeaux, Injalbert, Ding and even Rodin who showed interest for it. In addition, the famous French architects Garnier, Quesnel and Gaston Cousin, strongly recommended its use. Échaillon stone is therefore proposed here as a Global Heritage Stone Resource (GHSR) designation using the criteria outlined by Marker (2015).

\section{Geological Setting}

Échaillon stone was quarried from Mesozoic deposits of the western Alps.

\section{Structural and paleogeographical framework of the Western Alps}

The western Alps arc, from east to west, is characterized by several zones marked by specific relief and lithologies (Fig. 2a). 


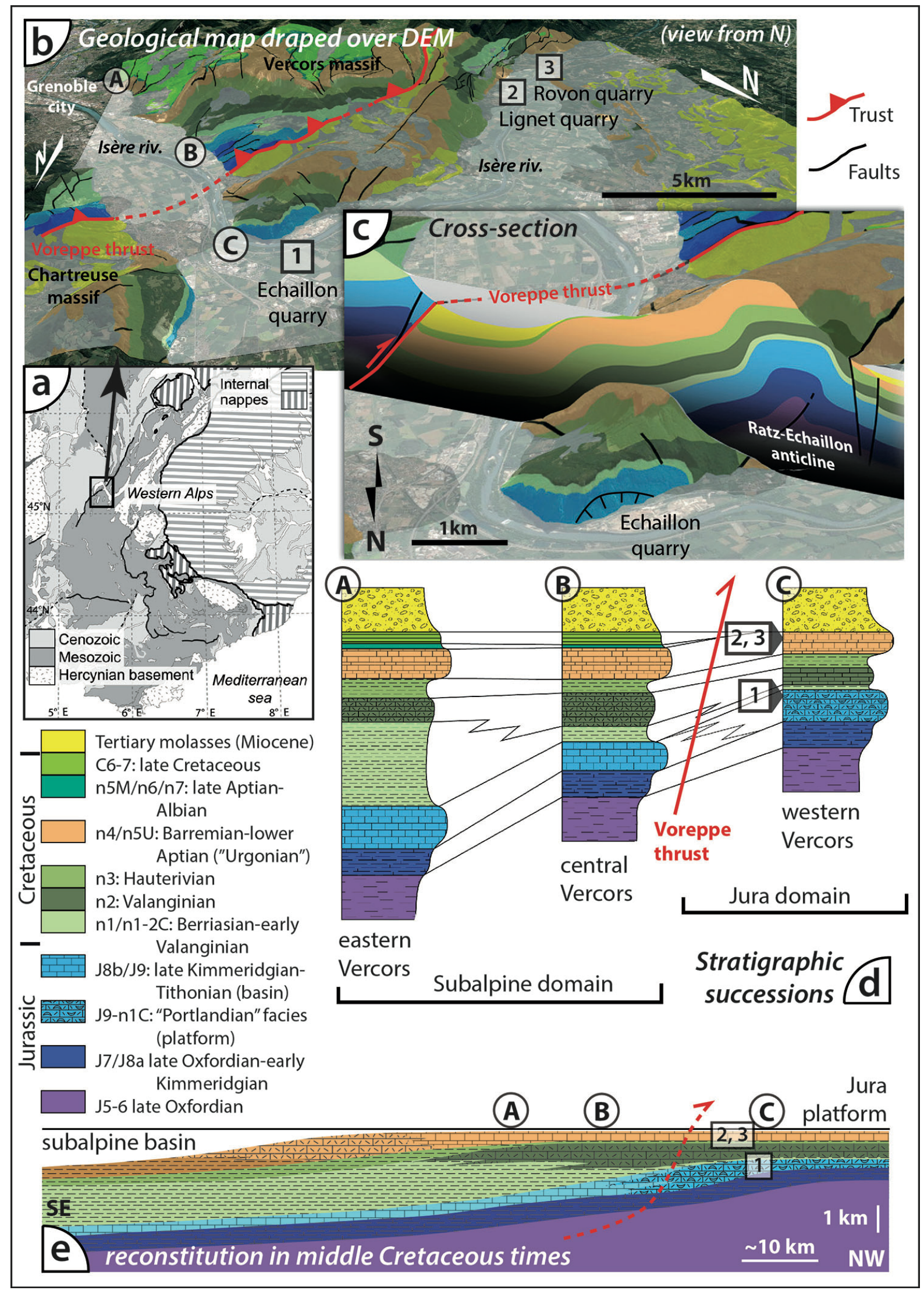

Fig. 2. Geological setting of the Échaillon (1) Lignet (2) and Rovon (3) sites. (a) Location in the western foreland of the Western Alps arc. (b) Geological map draped over digital elevation model, perspective view from the north. (c) Block-diagram combined with E-W 
cross-section (similar view from the north): the Échaillon limestone outcrops on top of a NStrending anticline, in the footwall of the Voreppe thrust. (d) Stratigraphic successions showing the lateral variations across the Vercors Massif, between the Jura platform and the subalpine basin, across the Vercors Mountain Range (Fig. 1). (e) Interpretative cross-section reconstructed in Cretaceous, to illustrate the SE-ward progradation of the platform margin from late Jurassic-Berriasian (Échaillon quarry, 'White Échaillon' and 'Pink Échaillon' varieties) to late early Cretaceous (Lignet and Rovon quarries, 'Yellow Échaillon' variety). A, $B$ and $C$ : different types of stratigraphic successions across the Vercors Massif, which were distributed during the Mesozoic from basinward location (A) to platform location $(C)$.

The internal zones are located in the core of the arc in France, Italy and Switzerland, and are composed of variably metamorphosed cover and basement napes. They are thrust westwards over the external zone along the Penninic thrust.

The external zone (or Dauphiné/Helvetic zone) is cored by the external crystalline massifs, composed of uplifted Hercynian metamorphic basement, which corresponds to the highest $\sim 3$ $4 \mathrm{~km}$ elevation of the Alps, i.e., Mont-Blanc, Belledonne, Écrins and Argentera massifs. The foreland area to the west, is rimmed by Mesozoic strata of moderate $\sim 1-2 \mathrm{~km}$ elevation typical of the Bornes, Bauges, Chartreuse and Vercors 'subalpine' massifs.

Further west, the lower foreland is dominated by Tertiary shallow-water to continental molasses, controlled by syn-orogenic erosion with local fold-and-thrust propagation. The Échaillon, Lignet and Rovon quarries are located at the western edge of the Vercors Massif, in proximity to the boundary with the Tertiary foreland (Fig. 2b-c).

The geodynamic forces that formed the western Alps occurred with the closure of the Tethys Seaway that developed in the middle Jurassic (Lemoine et al. 1986) and whose oceanic remnants were preserved in the internal zones of the orogenic wedge during the Tertiary collision (Dumont et al. 2011 and references therein). Considering the Mesozoic sedimentary record, the external zone is derived from the northwestern flank of the European passive margin of the Tethys Seaway.

At that time, this area in the Vercors Massif was located close to the hinge between the Jura platform to the NW and the Vocontian Basin to the SE. This hinge migrated through time as the relative sea-level oscillated due to the changes in local subsidence and global eustacy (Jacquin et al. 1991). Thus, the late Jurassic-Cretaceous stratigraphic record (Gidon \& Arnaud, 1978) shows periodical development of shallow-water platform carbonates interbedded with deeper ramp deposits or basinal marls (Fig. 2d-e). The Échaillon quarry and the Lignet and Rovon quarries are excavated in two distinctive platform-carbonate formations, of Late Jurassic (Tithonian) age and of early Cretaceous (Barremian-early Aptian) age, respectively.

Prior to the formation of the thrust front, this area was uplifted during the Oligocene Epoch as the eastern shoulder of the Rhône Valley extensional graben. By Miocene time, the westward fold-and-thrusting occurred (Philippe et al. 1998; Fig. 2c), with the uplift of the Vercors Massif, bringing the Mesozoic strata near to the surface. During the Quaternary Period, climatic events formed the Alpine glaciers and the Isère River Valley. Eventually glacial and fluvial erosion of the valley exposed the Mesozoic rocks that are now recognized as the Échaillon, Lignet and Rovon quarries.

\section{Stratigraphy, Sedimentology, and Paleontology}

The Échaillon, Lignet and Rovon quarries, now inactive, represent two different Mesozoic formations of Late Jurassic to Early Cretaceous age. 
The lithology of the Échaillon quarry represents the southernmost extent of shallow-water limestones that prograded from the Jura platform during the late Jurassic to early Cretaceous (Enay et al. 1984). Échaillon limestone is a lagoonal to peri-reefal facies probably deposited towards the platform edge separating the back-reef, lagoonal and lacustrine domains (Portlandian facies) from the basin. To the SE, these strata grade laterally into deeper water facies, such as pelagic calpionellid micritic limestones (Gidon \& Arnaud 1978), but exposure of this transition is presently crosscut by the Voreppe thrust (Fig. 2b-c) or is eroded. Although similar in age, the Échaillon shallow-water limestone is markedly different from the pelagic Tithonian-Berriasian micritic limestone which was also exploited for architectural features until the end of the 19th century near Grenoble, $15 \mathrm{~km}$ SE of l'Échaillon. In the main Échaillon quarries (cross-section Fig. 3a-b) the Échaillon limestone is a bioclastic packstone/grainstone, with some dolomitic patches, and some sparry calcite cement (Dunham. 1962). Isolated coarse carbonate bioclasts are mixed with fine carbonate sand, the by-product of high-energy reworking. Two varieties were exploited from the main Échaillon quarry, the 'White Échaillon' and the 'Pink Échaillon' stones (see below Fig. 3c).

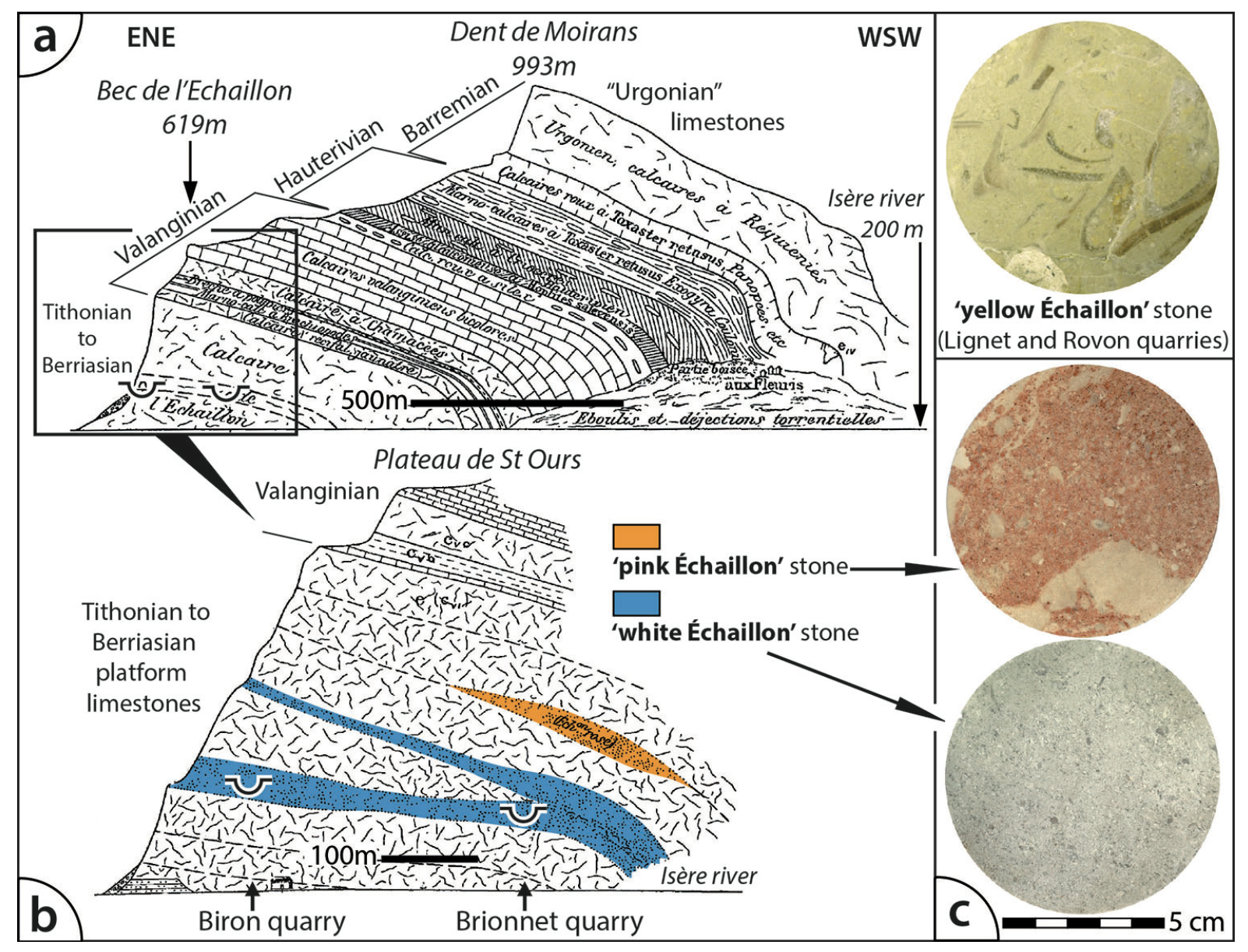

Fig. 3. (a) Geological section of the Échaillon promontory and (b) detail of the exploited layers of White and Pink Échaillon stones, with location of the Échaillon main quarries (after Kilian \& Lory, 1900, p. 573-574); (c) macroscopic view of commercial representative samples of the three 'Échaillon stone' varieties, issued from the Biron \& $C^{i e}$ documents.

In thin sections, the microfacies of these two varieties correspond to fine to medium grained carbonate grainstone to packstone (Fig. 4a, d, b, e). The grains are all carbonate, with sizes typically ranging from 0.1 to $1 \mathrm{~mm}$, and include abundant echinoids and crinoids, echinoid 
spines, benthic foraminifera, brachiopods, bryozoans, bivalves (oysters) and gastropod debris, coral fragments, green algae, scarse oolites. The carbonate grains are affected by micritisation but angular shapes can be preserved never-the-less. The quite homogeneous distribution of the grains, with no obvious layering, is probably due to extensive bioturbation. Syntaxial calcite cement is frequently developed around echinoid clasts (Fig. 4d), suggesting that the initial sediment was probably a packstone and that sparry calcite is secondary.

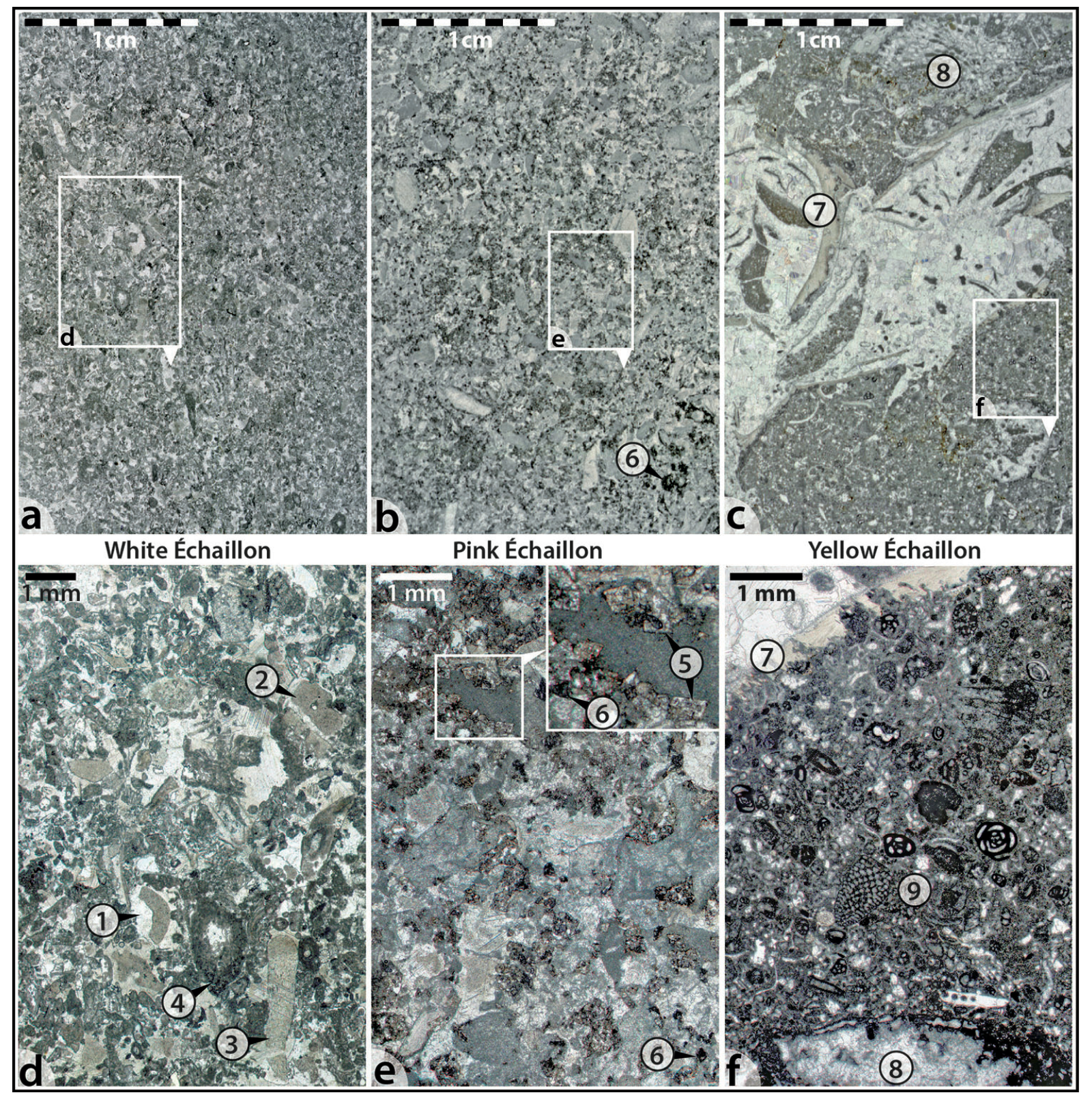

Fig. 4. Photomicrographs of thin sections (parallel polars) from the three varieties of 'Échaillon stone': (a, d) White Échaillon stone; (b, e) Pink Échaillon stone, and (c, f) Yellow Échaillon stone; Microfacies details: 1: syntaxial diagenetic cement developed over echinoid bioclasts; 2: crinoid bioclast; 3: echinoid spine; 4: micritized bioclast; 5: dolomite crystals overprinting bioclastic boundaries; 6; opaque iron oxyde (hematite) responsible for the pink colour of the 'Pink Échaillon' variety; 7: rudist shell with internal aragonite part (upper part) replaced by sparry calcite, and external, yellowish calcite part (lower part), preserved but affected by microperforations; 8: coral fragment, affected by peripheral micritization; 9: benthic foraminifera, including Orbitolinidae. 
From these criteria, the depositional environment may have correspond to a lagoonal setting, with bacterial activity and bioturbation, moderate energy and transport resulting in a mixture of different bioclasts, in a well-oxygenated environment, thus probably not far from the platform edge.

The specific colour of the 'Pink Échaillon' is due to diagenetic features (Fig. 4b-e). Initially similar to 'White Échaillon', the rock has been affected by dissolution crosscutting the cements and creating additional porosity. The latter enhanced fluid circulation and has been partly filled by dolomite crystals, and subsequently de-dolomitized, and by the addition of hematite giving the pink colour. These diagenetic alterations possibly occurred in association with an emersion of the platform.

The fossil content, studied since the middle 19th century, is described by Kilian \& Lory (1900) and Faure-Marguerit (1919) and includes 163 species: corals, lamellibranch molluscs, brachiopods, gastropods, echinoderms (crinoids and urchins), anelids, crustaceans and benthic foraminifera, all reworked in peri-reefal environments. Rare occurrence of cephalopods indicates the vicinity of open-marine environments which are actually found near Grenoble, about $20 \mathrm{~km}$ further SW. The benthic fauna are consistent with a stratigraphic range from latest Jurassic (Tithonian), to Early Cretaceous (Berriasian) in the youngest part of the stratigraphic sequence (Gidon et al. 1978), and the rare ammonites are all Tithonian in age (Faure-Marguerit 1919).

The Lignet and Rovon quarries, from which the 'Yellow Échaillon' stone was extracted (Fig. 1, Fig. 2b) were developed in Barremian-early Aptian platform limestones which prograded farther south than the Late Jurassic-Berriasian platform (Fig. 2e). This widespread formation is named 'Urgonian' and provides the main framework of the Chartreuse and Vercors massifs due to its thickness of 200 to $300 \mathrm{~m}$ and its resistance to erosion and weathering. The shelf facies range from the shoreline to the reef (Arnaud-Vanneau \& Arnaud 1990). Deposition of the shoreface, outer shelf and ramp facies was $50 \mathrm{~km}$ farther south (Jacquin et al. 1991). This limestone is similar in texture to the main Échaillon quarry lithology, but with coarser and better preserved macrofossils such as rudists. Stratigraphically, these facies are constrained by micropaleontology (Arnaud et al. 1998) and biostratigraphy (Clavel et al. 2014), together with the recent use of alternative geophysical/geochemical correlation tools (Raddadi et al. 2005).

In thin section, the microfacies of 'Yellow Échaillon' stone corresponds to fine grained carbonate wackestone to packstone containing large (centimetric) bioclastic fragments (Fig. $4 \mathrm{c})$. Small $(<\mathrm{mm})$ carbonate grains including benthic foraminifera, green algae and various bioclastic fragments are included in a carbonate muddy matrix (Fig. 4f). Large $(>\mathrm{cm})$ rudist and coral debris are common and in well preserved, thus not transported. Many debris are affected by micritisation, and the rudist shells bear evidence of dissolution, aragonitic parts having been replaced by sparry calcite (Fig. 4f). The quite homogeneous distribution of small bioclasts in the matrix is due to bioturbation. These criteria point to a very shallow (few metres water depth) and restricted depositional environment, corresponding to an internal lagoon.

From a stratigraphic point of view, the 'Urgonian' limestone section in Cognin-Gorges du Nan, $4 \mathrm{~km}$ south of the Rovon quarry, is dated as late Barremian-early Aptian based on the benthic foraminifera (Orbitolinidae) assemblages and on sequence stratigraphy (Gidon et al. 1978; Arnaud et al. 1998). The thin section sample presented in Fig. 4c and Fig. 4f contains foraminifera typical from late Barremian to early Aptian (A. Arnaud-Vanneau, pers. comm. January 2020). 


\section{Global Heritage Stone Resource candidacy requirements}

To be considered for GHSR nomination, the Heritage Stone Task Group (HSTG) Terms of Reference state that citations shall contain certain specific information, as follows:

- 'Échaillon stone' is the proposed formal name. An alternative designation occasionally found is 'Échaillon marble', but it is not correct from a geological point of view because this limestone is not metamorphic. The calcareous grains composing it are bioclasts (see microfacies descriptions above) and are not due to high temperature recrystallization as expected in marbles.

- The origin of this name comes from a local rocky headland called 'l'Échaillon', where the main quarries are located. It forms the northernmost edge of the Vercors Mountain range, and is surrounded by a bend in the Isère River approximately $15 \mathrm{~km}$ downstream from the city of Grenoble. In old French language, 'Échaillon' would mean a place with stones and rocks (Prégorier 2006).

- The Stratigraphic name for the late Jurassic varieties is 'Portlandian' facies and consist of shallow-marine limestone of Tithonian age, whereas the early Cretaceous variety is called 'Urgonian' facies and is a shallow marine limestone of Barremian age.

- Other names are given to the three different varieties (Fig. 3): White Échaillon No. 1, one of the late Jurassic variety ('Portlandian' facies, Tithonian in age), is a beautiful limestone with an appearance and texture similar to white marble. It is suitable for use in sculptures and can be worked on lathes and planes (Kilian \& Lory 1900). It is weather resistant which makes it suitable for exterior use. Pink Échaillon No. 2, the second late Jurassic variety, is a hard, very fine-grained, partly crystalline limestone with a pinkish colour due to diffuse hematite content. This limestone was used in sculptures and for outdoor applications. Yellow Échaillon No. 3 is a dense, finegrained platform limestone of early Cretaceous (Barremian to early Aptian) age. It takes a high polish that gives the appearance of brocatelle marble. It can be easily carved and worked on lathes for use as indoor columns and pillars. Yellow Échaillon No. 3 is also weather resistant, which makes it applicable for outdoor use. Although sold as Échaillon stone, this third variety was not quarried in the same place as the others, but in two nearby villages (see below).

- Commercial designations of these three varieties are, respectively, White Échaillon $\mathrm{n}^{\circ} 1$, Pink Échaillon $\mathrm{n}^{\circ} 2$, and Yellow Échaillon $\mathrm{n}^{\circ} 3$. The Biron works also commercialised some other stones that were not Échaillon stone.

- The area of occurrence includes three localities at the western termination of the western Alps, south-east France (Fig. 1). The quarries are located at the toe of the north-western edge of the Vercors Mountain range, on the left bank of the Isère River between $15 \mathrm{~km}$ and $30 \mathrm{~km}$ downstream from the city of Grenoble.

- The principal location of the quarries is as follows: The Échaillon main quarries, from which are derived the 'White Échaillon' and 'Pink Échaillon' varieties, are located near Saint-Quentin-sur-Isère, on a rocky slope headland named 'l'Échaillon' (coordinates $45^{\circ} 18^{\prime} 01.20^{\prime \prime} \mathrm{N} ; 5^{\circ} 36^{\prime} 04.10^{\prime \prime} \mathrm{E}$ ). There are two ancillary quarries, where the 'Yellow Échaillon' variety comes from, the Le Lignet quarry, located $14 \mathrm{~km} \mathrm{SW}$ on the left bank of the Isère River $\left(45^{\circ} 12^{\prime} 59.39^{\prime \prime} \mathrm{N} ; 5^{\circ} 29^{\prime} 49.69^{\prime \prime} \mathrm{E}\right)$ near a village named 'La Rivière', and the Rovon quarry (45'11'23.50” N; 5²7'14.33” E).

- The petrographic name of the three varieties of 'Échaillon stone' is carbonate bioclastic grainstone to packstone (Dunham 1962). These stones are carbonates, with a 
small amount of magnesium carbonate (dolomite), varying from traces to $3 \%$, and all grains are of bioclastic origin (see Fig. 4 and microfacies description above).

- The primary colours of the three varieties are white, light pink and light yellow (Fig. 3). Besides colour, the unique aesthetics of this stone both for sculpture and architecture is provided by its fine-grained texture and hardness due to homogeneous cementation by sparry calcite.

- The natural variability of this stone is explained by its particular stratigraphic origin derived from both Jurassic and Cretaceous strata. The white variety derived from the Échaillon main quarries, which represents about $70 \%$ of the total production, is easily distinguishable from the yellow one (about 22\%) and from the pink one, which is only marginally produced $(<10 \%)$ (Fig. 5).

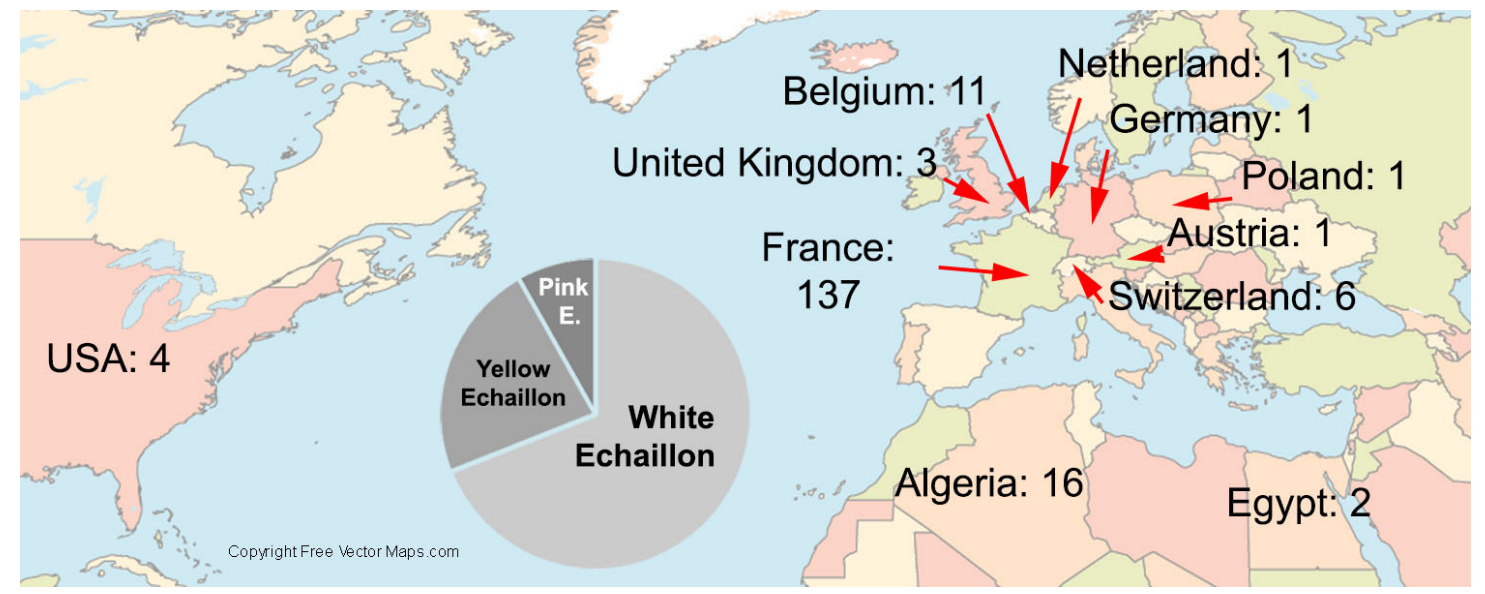

Fig. 5. Worldwide occurrence of monuments built using 'Échaillon stone', and the relative percentages of the three varieties (grey pie chart).

- Composition of the three varieties is calcium carbonate, with a small amount of dolomite in the white and pink varieties (less than $3 \%$ ) and $<1 \%$ hematite in the pink variety (Biron G \& $\mathrm{C}^{\mathrm{ie}}$ 1877).

- Technical properties data available in the literature are few. The main parameters were measured as follows (Biron $\mathrm{G} \& \mathrm{C}^{\text {ie }} 1877$ ):

-White Échaillon: density $2.515 \mathrm{~g} / \mathrm{cm}^{3}$ to $2.534 \mathrm{~g} / \mathrm{cm}^{3}$, compressive strength 74.3 to $93.6 \mathrm{MPa}$.

-Pink Échaillon: density $2.358 \mathrm{~g} / \mathrm{cm}^{3}$ to $2.487 \mathrm{~g} / \mathrm{cm}^{3}$, compressive strength 56.7 to $69.4 \mathrm{MPa}$.

-Yellow Échaillon: density $2.468 \mathrm{~g} / \mathrm{cm}^{3}$ to $2.826 \mathrm{~g} / \mathrm{cm}^{3}$, compressive strength 59.1 to $106 \mathrm{MPa}$.

The water content during extraction was 0.2 to $0.8 \%$ in mass, which made the stone easier to carve before pore-water loss.

- Vulnerability, in particular resistance to freezing cycles, has been found to be among the best for limestone. Hardness of White Échaillon improves with time due to porewater loss, a characteristics which was advantageous for sculptural works.

- Suitability was thus diverse, corresponding to varieties: White Échaillon has been used in sculptural and ornamental works as well as interior and exterior building stones, columns, pillars, railings and grand staircases. Pink Échaillon was more restricted in use, mostly as columns and railings. Yellow Échaillon has been widely used in walls, columns, pedestals, paving and water fountains. 
- Maintenance of supply: the White Échaillon and Pink Échaillon stones were quarried in the Échaillon main quarries which were operated mainly by two companies: 'Société des Carrières et Usines de l'Échaillon Georges Biron \& Cie.', and 'MillyBrionnet et ses fils (Milly-Brionnet and sons)'. The Yellow Échaillon was quarried in the ancillary Le Lignet quarry, mainly operated by Georges Biron \& $C^{\text {ie }}$. It was also quarried in the Rovon quarry, mainly operated by the 'Milly-Brionnet et ses fils' (Milly-Brionnet and sons) company. Production for building and ornamental stones has been discontinued in the three quarries since the first decade after the Second World War. To the SW of Le Lignet quarry, at La Rivière, a large limestone quarry is still in operation and produces crushed stone for road works, gabions, rip-rap, and various other uses from the Yellow Échaillon variety. It is presently operated by the Budillon-Rabatel company.

\section{Historic Use and Geographic Area of Utilization}

\section{Historical development}

Échaillon stone was in use in Gallo-Roman times (the third century columns in the crypt of Saint-Laurent church in Grenoble), the Middle Ages and the Renaissance in Grenoble (portal of Saint André's church, portal and ogival chapel of the Court Hall, pediment of the arch of the "Porte de France", balustrades of the town gardens, etc.) (Debelmas 1990). Production appears to have temporarily ceased towards the end of the eighteenth century.

Operations resumed and were developed from 1848 by Etienne Bernard, and then, in 1853 by Jean François Papet-Biron and his son Pierre Papet-Biron. Since 1873, the grandson, Georges Biron, together with Jacques-Aimé Milly-Brionnet (and with his sons later on) have opened quarries whose products have gained a high reputation and were sent to all regions of France and abroad.

Georges Biron died in 1921, and the Biron and Milly-Brionnet quarries subsequently declined until the decade after the end of the Second World War (SPIA 2019). Difficulties of access to the quarries, lack of manpower after the First World War, and introduction by Vicat of 'moulded cement' as a replacement for building stone (especially in the Grenoble area where it was first introduced), were amongst the reasons for the decline and the end of production. The longest to survive was Milly-Brionnet, having shifted its activity from building stone to crushed limestone production.

\section{Worldwide geographical area of utilisation of Échaillon stone}

The worldwide distribution of monuments or sculptures made or partly made of Échaillon stone is given in Fig. 5. Some of the best examples of Échaillon stone utilisation from around the world are described below, in chronological order:

- Saint-Andre collegiate church in Grenoble, France, dates from about 1220. The sculpted parts of the main portal in Romanesque style are in White Échaillon (Fig. 6). This is a valuable example of Échaillon stone utilization dating from before the industrial era. The clock face, also in White Échaillon dates from 1851. 
Fig. 6. Romanesque portal of SaintAndre collegiate church in Grenoble, France. A brownish patina is acquired by the White Echaillon stone through long time ( 800 yrs.).

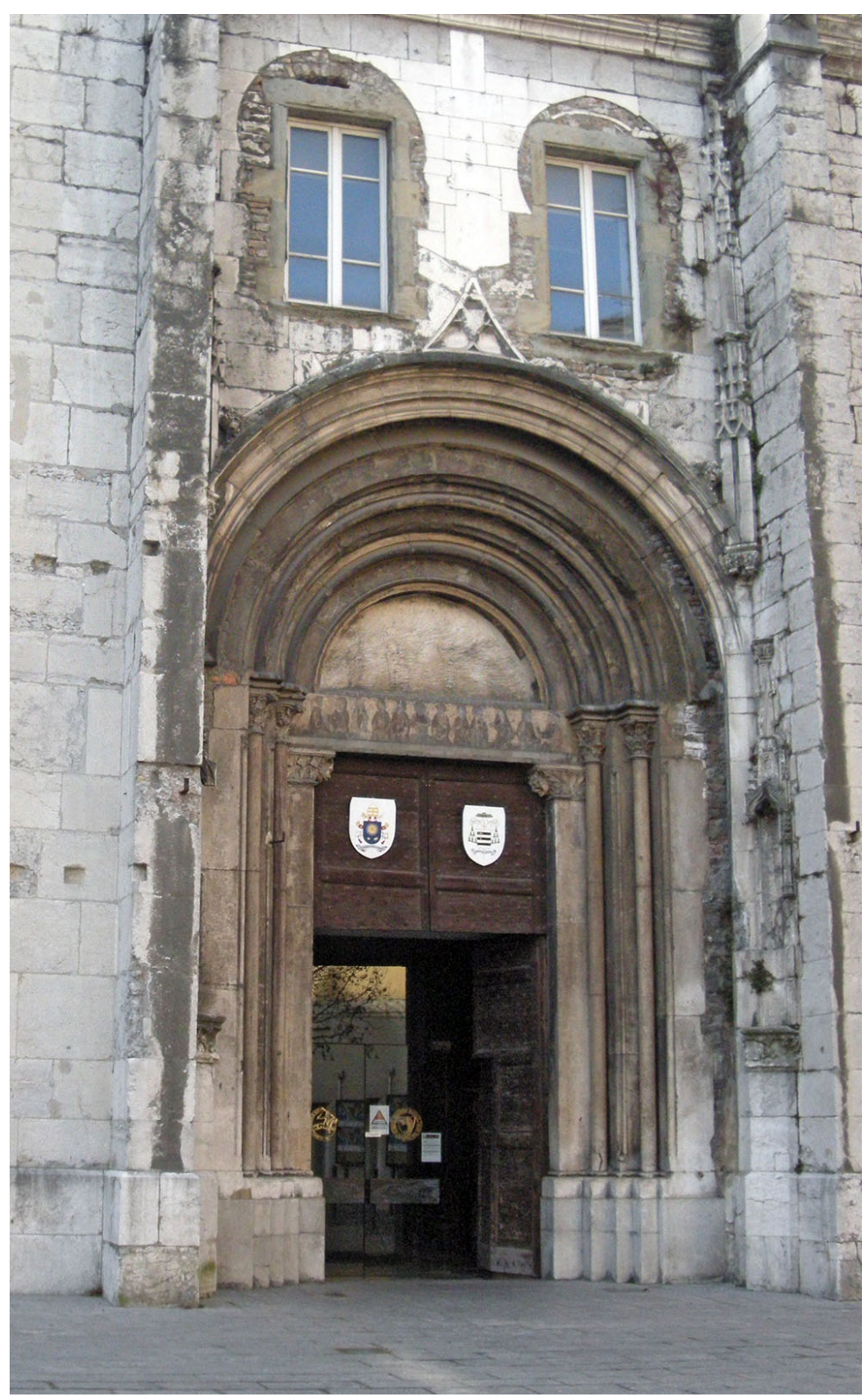

- The basilica of Sainte Anne d'Auray, Sainte-Anne d'Auray, Brittany, France, was constructed starting from 1866, under the direction of architect Édouard Deperthes. The entire high altar is in White Échaillon. The side altars are also in White Échaillon. Various pavings are in White, Pink and Yellow Échaillon.

- The memorial monument to Augustin Ausonne de Chancel in Suez, Egypt, entirely made in White Échaillon, commemorates the death, in Cairo, in February 1867, of the managing director of the Universal Company of the Suez Canal who worked with Ferdinand de Lesseps during construction of the canal.

- The Paris Opera House is an illustrious monument containing Échaillon stone. It was created by architect Charles Garnier and inaugurated in 1875. Several elements of the façade are made of White Échaillon including the four sculpted groups representing dance, music, poetry (or harmony) and lyric drama (Fig. 7). The stone block carved by 
Carpeaux for the dance group weighed 33 tons when transported from the quarry works. A large number of interior and exterior architectural features of the building are made of White, Pink and Yellow Échaillon.
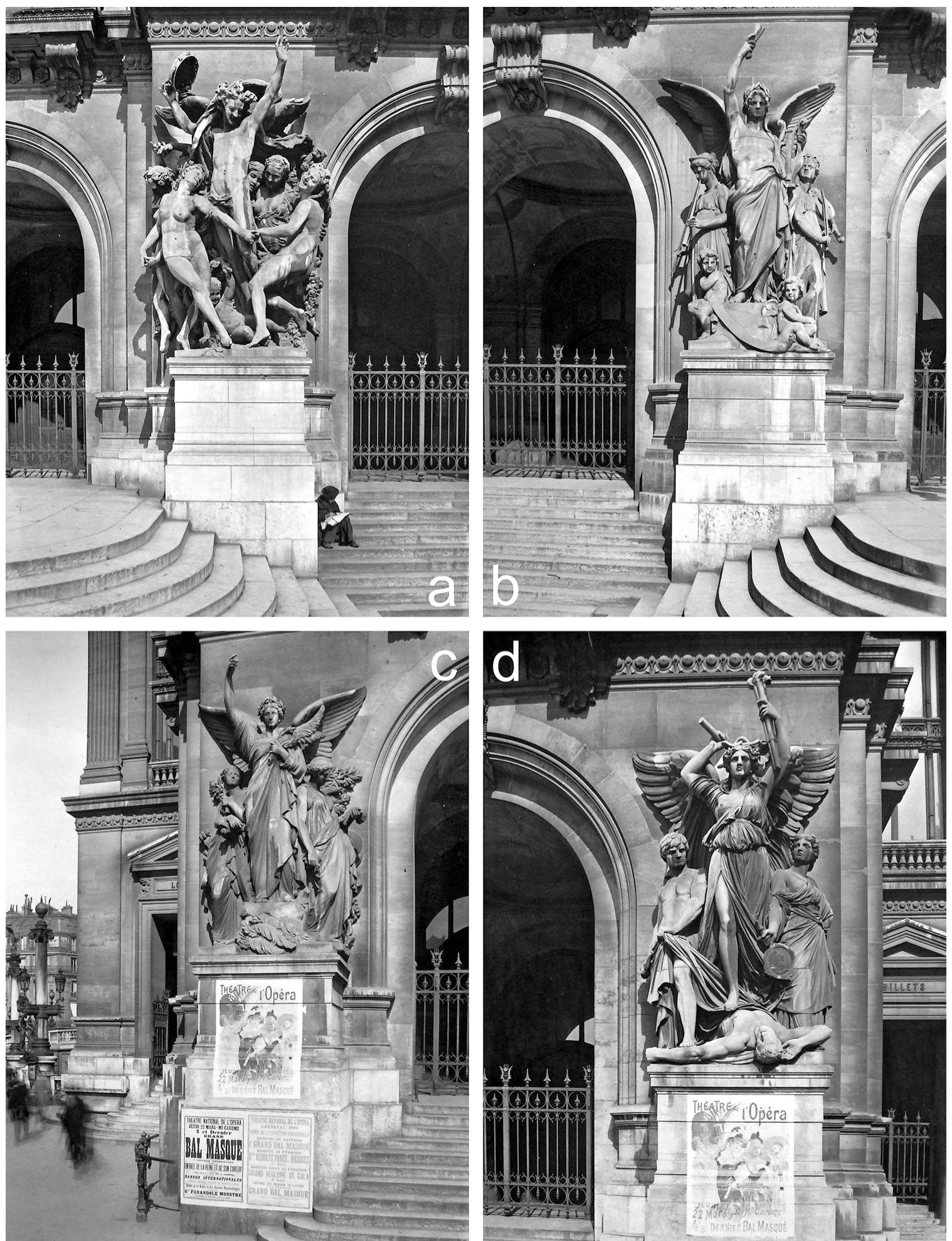

Fig. 7. Paris Opera House sculpted groups, dance (a), music (b), poetry, also known as harmony (c) and lyric drama (d), all in White Échaillon, Paris, France. 
- The memorial monument to the family of Pierre Idt (ca. 1889) located in Kouba cemetery near Algiers, Algeria is in White Échaillon for the foundation slab, and Yellow Échaillon for the remainder of the monument.

- The memorial monument to Ernest Doudard de Lagrée was installed in 1897 in Grenoble, France. The architect was Alfred Recoura, brother-in-law of Georges Biron, and the artist Auguste Rubin was a friend of Auguste Bartholdi. (Fig. 8). Doudard de Lagrée was leader of the French Mekong Expedition in 1866-1868. The monument built in White Échaillon was moved in 1968 to Saint-Vincent-de-Mercuze, the nearby village where Doudard de Lagrée was born and where his remains now rest.

Fig. 8. Monument in memory of Ernest Doudard de Lagrée, made in White Échaillon variety, located in SaintVincent-de-Mercuze, France.

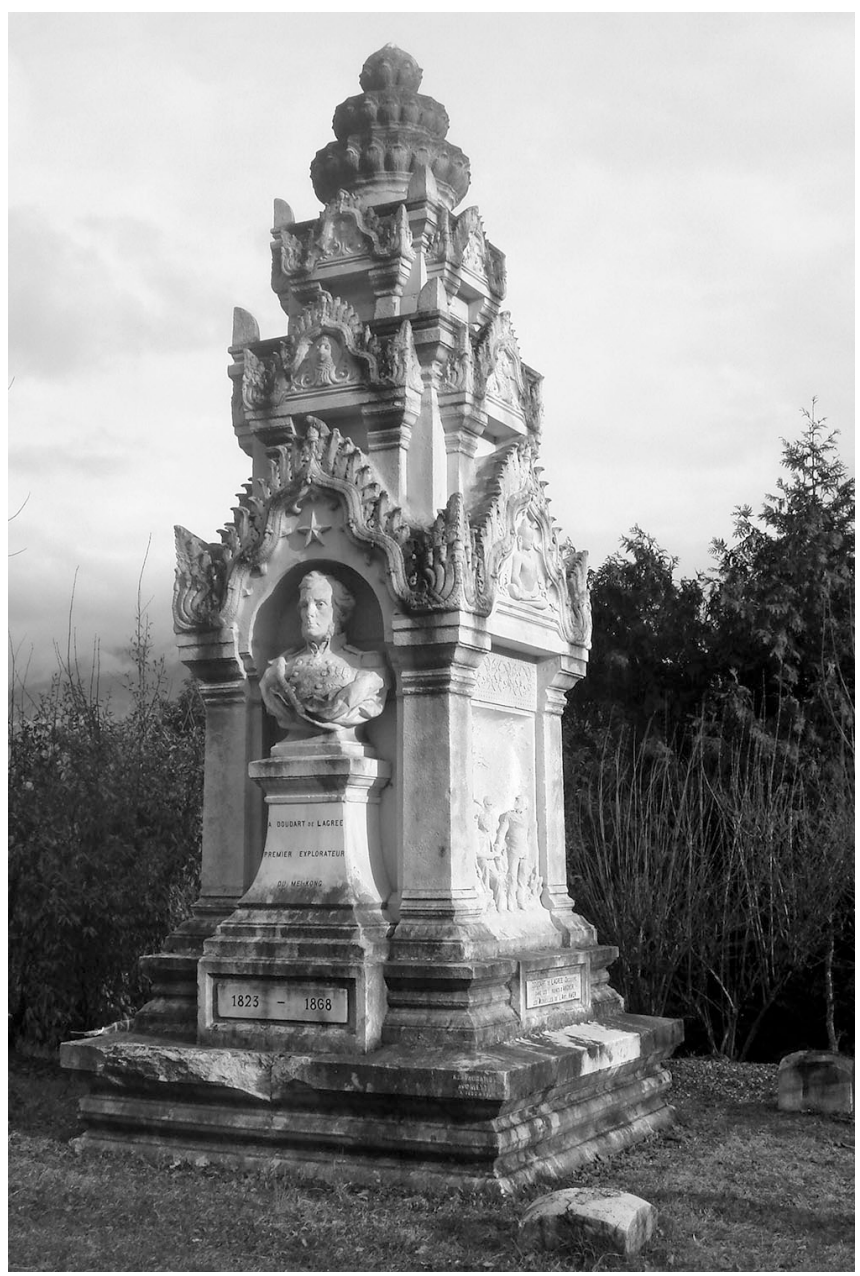

- A memorial monument to Adolphe Alphand by sculptor Aimé Jules Dalou and architect Jean-Camille Formigé was inaugurated in Paris in 1899 (Fig. 9 down). Under Napoléon III, Alphand participated in the renovation of Paris directed by Baron Haussmann. This monument is noteworthy because it is entirely built in White Échaillon, which is well documented in the Biron \& $C^{\text {ie }}$ works brochures. One of the largest monoliths extracted in the Échaillon quarry for this monument had a volume of 11.5 cubic meters and a mass of almost 30 Tons (Fig. 9 up). 
Fig. 9.

Large block of stone extracted from the underground part of the main Échaillon quarry for the monument to Adolphe Alphand

\section{Monument to} Adolphe Alphand entirely made of White Échaillon stone, inaugurated in 1899 in Paris, France.

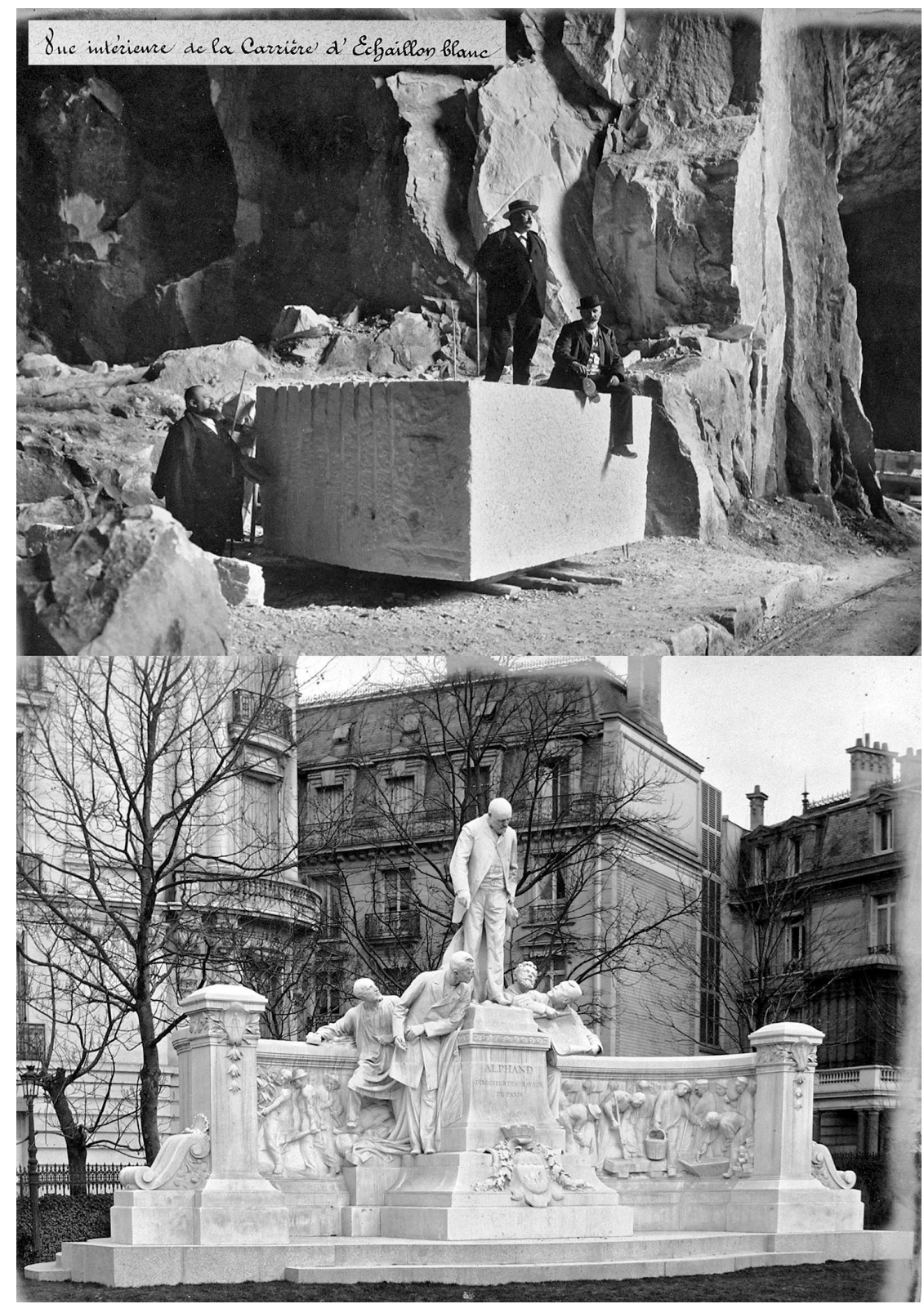

- The Alexandre III Bridge over the Seine River was inaugurated in 1900 for the International Exhibition in Paris, and was later registered as a French 'Monument historique' in 1975. The base of each of the $17 \mathrm{~m}$ high pillars erected at the four corners of the bridge, and part of the adjoining staircase are made of Yellow Échaillon (Fig. 10). 
Fig. 10.

Stone carvers at work in 1898 in the Échaillon quarry, preparing the bases of the pillars of the Alexandre III Bridge in Paris. From left to right, stone carvers, Jean Juvin and the director Georges Biron (photograph graciously lent by Mrs Tan, granddaughter of Jean Juvin).

Alexandre III bridge abutments staircases, made of White Échaillon stone, Paris, France.

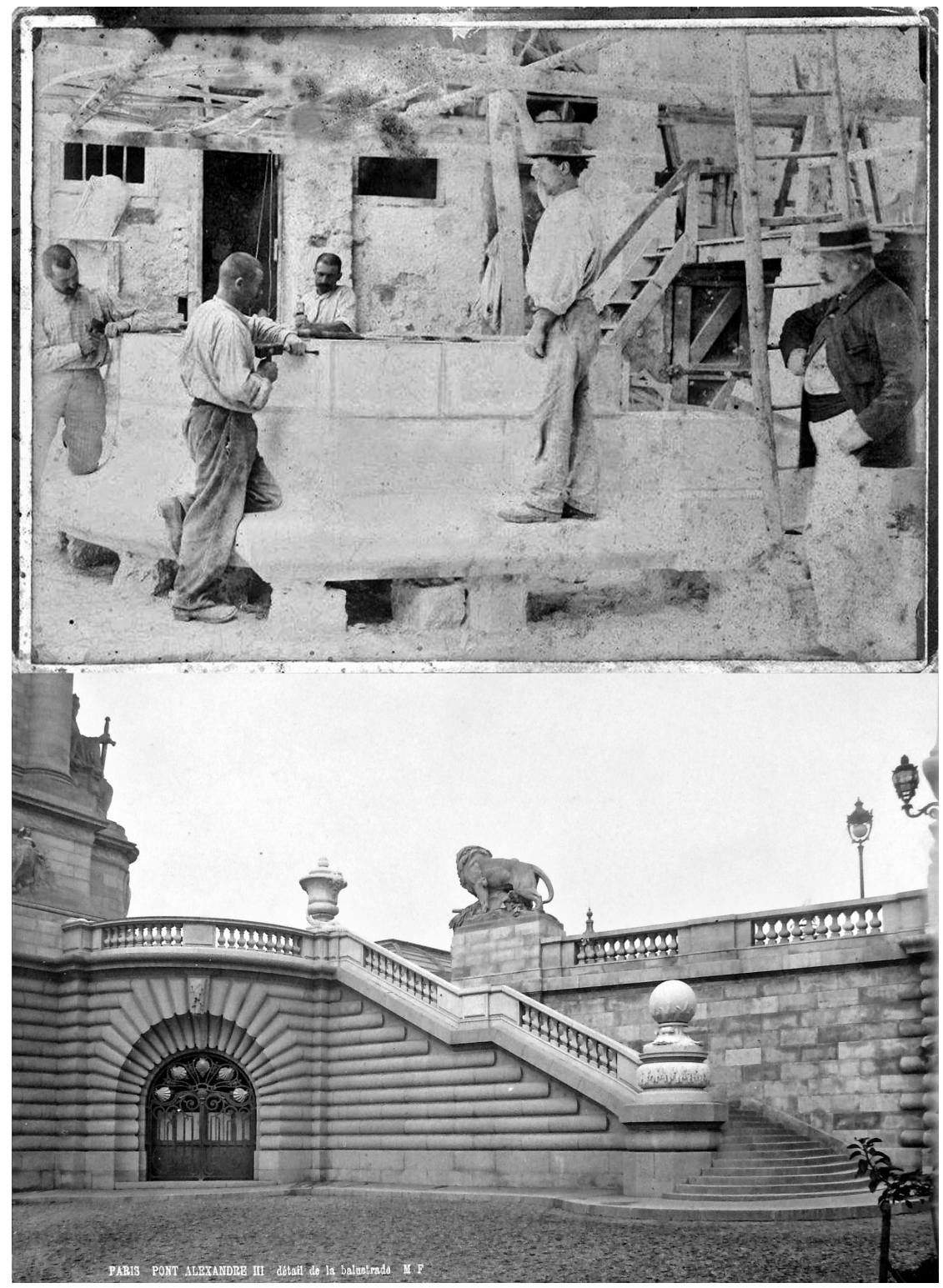

- The Ritz hotel in London, Piccadilly (1906), incorporates several elements made of White Échaillon: the grand staircases, the fountain and paving of the winter garden and the corridors.

- The Carnegie Museum in Pittsburgh (USA, PA), opened in 1907, incorporates several elements made of Yellow Échaillon: 82 tons in the columns and pillars, and 64 tons in the walls (Kollar et al. 2018; Fig. 11). 

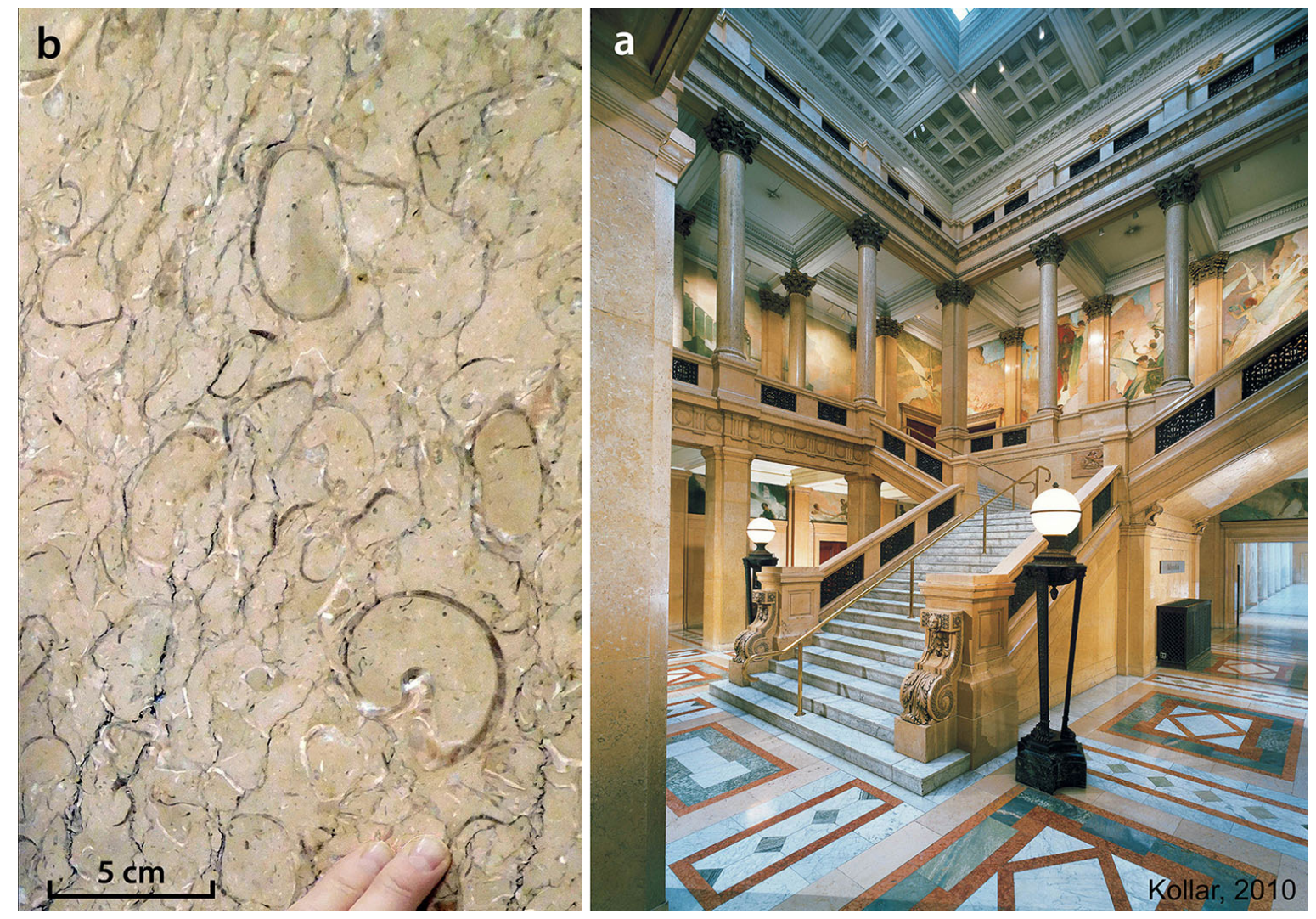

Fig. 11. Carnegie Museum of Natural History, Pittsburgh, Pennsylvania, U.S.A.: (a) Grand staircase hall: columns, pillars, and music hall foyer walls are made of Échaillon stone. (b): close-up view of a pillar wall made of Yellow Échaillon variety of early Cretaceous age, showing abundant rudist shells. (photos A. Kollar, 2010).

\section{Related Heritage Issues}

Remarkably, the famous sculptor Auguste Rodin was interested in the Échaillon stone for his project 'Le Génie du Repos Éternel' (The genius of eternal rest). The archive of the Rodin Museum in Paris, France, contains a price quote from Biron, addressed to Rodin for the White Échaillon. Unfortunately, Rodin abandoned the project in 1912.

The operators of the Biron quarries also maintained close relationships with the scientific community. They were a consistent partner and supplier of fossils to the Geology department of the University of Grenoble when Wilfrid Kilian and Pierre Lory were Director and Deputy Director, respectively (Kilian \& Lory 1900). The former has built a paleontological reference collection which is still accessible at the University Grenoble Alpes repository. Wilfrid Kilian also organised a post-congress field excursion following the eighth International Geological Congress held in Paris in 1900 (Kilian \& Lory 1900, Puche Riart et al. 2008). This excursion included a visit to the Échaillon quarries by a group of international participants (Fig. 12). 


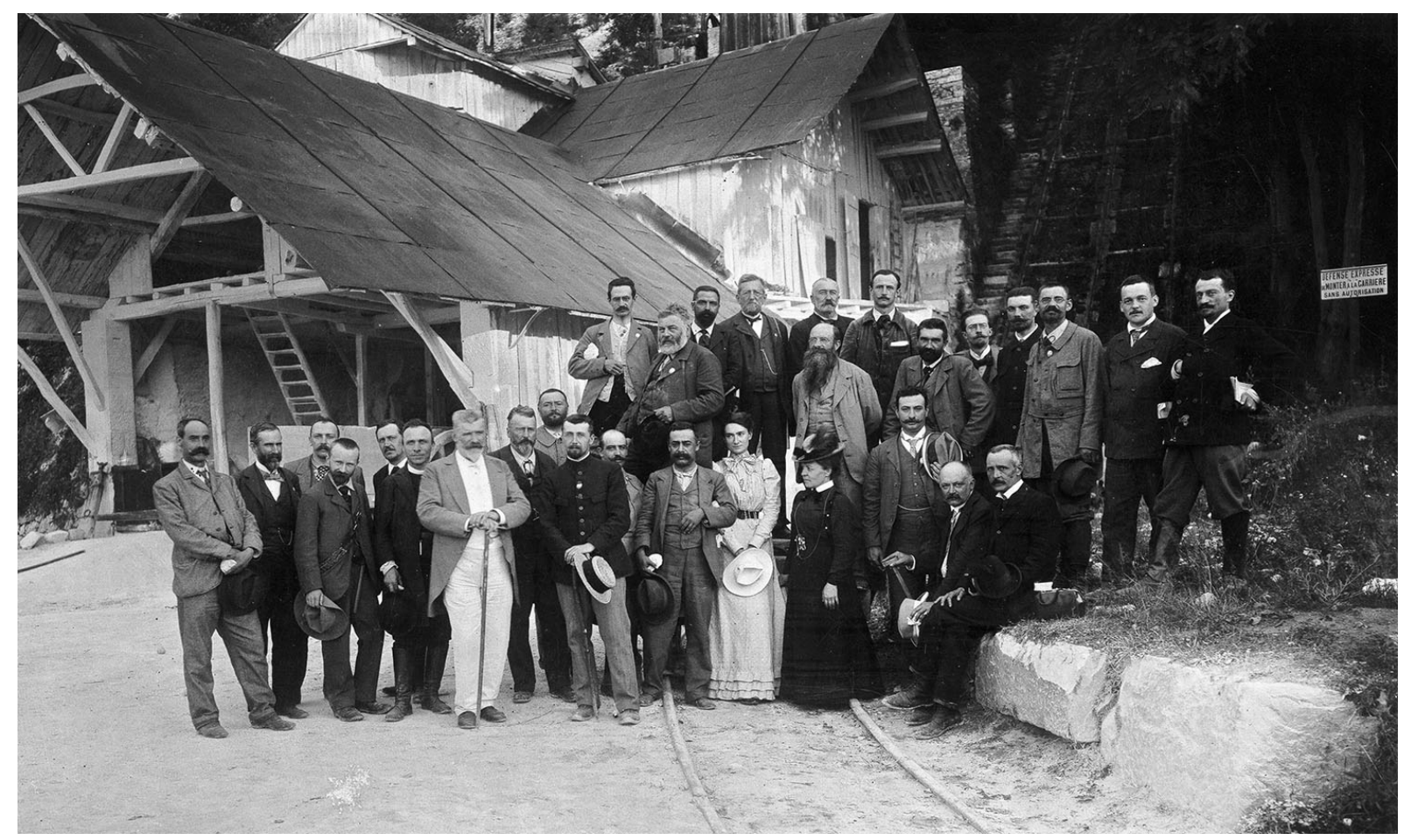

Fig. 12. During the eighth International Geological Congress held in Paris (1900), a group of international geologists visited the Échaillon quarries (1900). In front, standing with canes, are Georges Biron (in white, hosting the visit), and besides him to the right (with hat) Wilfrid Kilian, Director of the Geology Department of Grenoble University.

\section{Related Dimension Stones}

The Ratz-Échaillon anticline (Fig. 2b-c) is crosscut by the Isère valley (Fig. 2b). On the right bank of the river, that is on the opposite side to the Échaillon main quarry, the equivalent Late Jurassic limestone crops out in the core of the anticline at the southern edge of the Chartreuse massif. Here, a quarry which was active during the same period as the Échaillon site yielded a stone called 'Ratz stone', that has been used in a few monuments under the supervision of G. Biron (a fountain, dedicated to the centennial of the French Revolution in Grenoble, 1896; and an additional monument to the French Revolution, named La Liberté, in Vizille nearby Grenoble, 1888).

\section{Conclusions}

The Échaillon stone is a very specific peri-reefal facies which developed in Late Jurassic and Early Cretaceous times at the south-eastern edge of the Jura platform. It had already been identified as an appropriate material for building and sculpture in Gallo-Roman times, and was exploited and exported in Europe and overseas during the second half of the 19th century. During this period, it was chosen by world renowned Beaux-arts architects and sculptors for luxury buildings and ornamental purpose, and it could support the development of architecture in big cities following the Industrial Revolution. This stone exhibits all the attributes of a Global Heritage Stone Resource (GHSR). It is found in three varieties, socalled White, Pink and Yellow Échaillon stones. The white coloured stone, the most frequently used, is exceptionally close in appearance to marble, which makes it ideal for use 
in sculptures. In addition, the increasing hardness of this stone through time makes it also appropriate for exterior architecture. The pink and yellow varieties were dominantly used in architecture, throughout the interior of 19th century for building elements such as pedestals, columns, pillars, walls and staircases, as well as exterior walls, pedestals and water fountains. The occurrence of this exceptional calcareous stone in the Alpine foreland, was due both to (i) Mesozoic paleogeography which located carbonate production and high energy peri-reefal environments in a narrow strip at the edge of the Jura platform, with specific shallow-marine environments during climatically favourable periods of high carbonate production triggering calcareous grain production, cementation and diagenesis, and (ii) to compressional Alpine deformation reactivating this paleogeographical boundary and providing exhumation of the productive layers at the hinge between the fold-and-thrust belt (Subalpine massifs) and the foreland molassic basin. Despite the lack of knowledge about modern geodynamic concepts, sedimentology and sequence stratigraphy, this opportunity had been detected very early and a worldwide excellent reputation developed, allowing export to other countries in Europe, North Africa and the United States of America.

\section{Acknowledgments}

We would like to hereby acknowledge the instrumental impulse and follow-up provided during the elaboration of this contribution by Albert D. Kollar. We are grateful to two anonymous reviewers who greatly improved the manuscript. We are also grateful to Steve G. Matthews for checking English writing, to Annie Arnaud-Vanneau for microfacies analysis and to Joseph T. Hannibal for final check of the manuscript.

Unless otherwise noted, photographs in this article are from SPIA members and reproductions from Georges Biron \& Cie. old promotional brochures.

\section{References}

Arnaud-Vanneau, A. \& Arnaud, H. 1990. Hauterivian to lower Aptian carbonate shelf sedimentation and sequence stratigraphy in the Jura and northern subalpine chains (southeastern France and Swiss Jura). In: Tucker, M.E., Wilson, J.L., Crevello, P.D., Sarg J.R. \& Read J.F. (eds) Carbonate platforms, Facies, Sequences and Evolution., International Association of Sedimentologists Special Publication, 9, 203-233.

Arnaud, H., Arnaud-Vanneau, A., Blanc-Aletru, M.C., Adatte, T., Argot, M., Delanoy, G., Thieuloy, J.P., Vermeulen, J., Virgone, A., Virlouvet, B. \& Wermeille, S. 1998. Répartition stratigraphique des orbitolinidés de la plate-forme urgonienne subalpine et jurassienne (sud-est de la France). Géologie Alpine, Grenoble, 74, 3-89.

Biron $\mathrm{G} \& \mathrm{C}^{\mathrm{ie}} 1877$. Notice sur les carrières de l'Échaillon près Grenoble, Isère. P. Allier père \& fils, Grenoble, 10-13

Clavel, B., Charollais, J., Busnardo, R., Granier, B., Conrad, M., Desjacques, P. \& Metzger, J. 2014. La plate-forme carbonatée urgonienne (Hauterivien supérieur-Aptien inférieur) dans le sud-est de la France et en Suisse: synthèse. Archives des Sciences de Genève, 67(1), 1-100.

Debelmas, J. 1990. Les anciennes carrières de Grenoble et de ses environs immédiats. Géologie Alpine, Grenoble, 66, 11-22.

Dumont, T., Simon-Labric, T., Authemayou, C. \& Heymes, T. 2011. Lateral termination of the north-directed Alpine orogeny, and onset of westward escape in the Western Alpine arc: structural and sedimentary evidence from the external zone. Tectonics, 30, doi:10.1029/2010TC002836 
Dunham, R.J. 1962. Classification of carbonate rocks according to depositional texture. In: Ham, W.E. (ed) Classification of carbonate rocks. American Association of Petroleum Geologists, Memoir, 1, 108-121.

Enay, R. \& coll. 1984, Jurassique supérieur, In: Debrand-Passard, S., Courbouleix, S. \& Lienhardt, M.J. (eds) Synthèse géologique du sud-est de la France, Bureau de Recherches Géologiques et Mininères, Orléans, Mémoire, 125, 223-286.

Faure-Marguerit, G. 1919. Monographie paléontologique des assises coralligènes du promontoire de l'Échaillon (Isère). Travaux du Laboratoire de Géologie de l'Université de Grenoble (Géologie Alpine), 12, 9-108.

Gidon, M., Arnaud, H. \& collaborateurs 1978. Carte géologique de France à 1/50000ème, feuille Grenoble et notice, Bureau de Recherches Géologiques et Mininères, Orléans.

Jacquin, T., Arnaud-Vanneau, A., Arnaud, H., Ravenne, C. \& Vail, P. 1991. Systems tracts and depositional sequences in a carbonate setting: a study of continuous outcrops from platform to basin at the scale of seismic lines. Marine and Petroleum Geology, 8, 122139.

Kilian, W. \& Lory, P. 1900. Notice sur les assises jurassiques et crétacées du promontoire de l'Échaillon, In: Kilian W. \& Lory P. (eds) Notices géologiques sur divers points des Alpes françaises, Livret-guide des excursions du 8è Congrès Géologique International. Travaux du Laboratoire de Géologie de l'Université de Grenoble (Géologie Alpine), 5, 3, 568-595.

Kollar, A., Fedosick, R., \& Hughes, K. 2018. The Signature Dimension Stones used by Longfellow, Alden and Harlow, Architects - In Classical Pittsburgh Architecture from 1887 - 1910. Geological Society of America Abstracts with Programs, 50, 6.

Lemoine, M., Bas, T., Arnaud-Vanneau, A., Arnaud, H., Dumont, T., Gidon, M., Bourbon, M., de Graciansky, P.C., Rudckiewicz, J.L., Megard-Galli, J. \& Tricart, P. 1986. The continental margin of the Mesozoic Tethys in the Western Alps. Marine and Petroleum Geology, 3, 179-199.

Marker, B.R. 2015. Procedure and criteria for the definition of Global Heritage Stone Resources. In: Pereira, D., Marker, B.R., Kramer, S, Cooper, B.J., \& Schouenborg, B.E., 2015 Global Heritage Stone: Towards International Recognition of Building and Ornamental Stones. Geological Society Special Publications, 407, 5-10, https://doi.org/10.1144/SP407.3

Pégorier, A. 2006. Les noms de lieux en France, dictionnaire des termes dialectaux. Institut Geographique National, Commission de toponymie. http://education.ign.fr/sites/all/files/glossaire_noms_lieux.pdf [accessed 15th February 2019].

Philippe, Y., Deville, E. \& Mascle, A. 1998. Thin-skinned inversion tectonics at oblique basin margin: example of the western Vercors and Chartreuse Subalpine massifs (SE France). Geological Society London special publication, 134, 239-262, doi:10.1144/GSL.SP.1998.134.01.11

Puche Riart, O., Mazadiego Martinez, L.F. \& Kindelan Etchevarria, P. 2008, The VIII International Geological Congress, Paris 1900. Episodes, 31, 3, 336-343.

Raddadi, M.C., Arnaud-Vanneau, A., Poupeau, G., Carrio-Schaffhauser, E., Arnaud, H \& Rivera, A. 2005. Interpretation of gamma-ray logs: the distribution of uranium in carbonate platform. Comptes Rendus Geoscience, 337, 1457-1461.

SPIA 2019. La pierre de l'Échaillon, Une histoire locale, une renommée internationale. SPIA Saint-Quentin-sur-Isère, France, 19-61. ISBN: 978-2-9559334-2-8. 